УдК 321.1

\author{
Ю. В. Чижмарь
}

\title{
СУЧАСНИЙ СТАН НОРМАТИВНО-ПРАВОВОГО РЕГУЛЮВАННЯ ТРУДОВИХ ВІДНОСИН У ФРАНЦІї
}

Постановка проблеми. На сьогодні розвиток ринкової економіки в країнах Заходу орієнтується на соціальний вектор. Такий напрям є наслідком соціальної інфраструктури в будь-якій західній країні, що складається з нормативних, юридично обов'язкових актів, які безпосередньо регулюють різні сторони суспільного й виробничого життя. Основною метою такої політики є зменшення негативних наслідків для працюючого населення та для всього суспільства від дії стихійних ринкових сил, насамперед на ринку найманої праці [1, с. 52].

Доцільність розгляду сучасного стану нормативно-правового регулювання трудових відносин у країнах Європейського Союзу полягає в тому, що досвід більш розвинених держав у багатьох випадках відображає ситуацію, яка через деякий час може скластись у менш розвинених країнах. Тому вивчення закордонного досвіду допомагає виділити аспекти, які можуть бути адаптовані в процесі національної правотворчості.

Стан дослідження. Сучасний стан нормативно-правового регулювання трудових відносин у країнах Європейського Союзу вивчали С.В. Буряк, Д.О. Гредякін, І.А. Грицяк, В.М. Завгородня, А.Я. Капустін, А.Л. Козик, I.Я. Кисельов, Н.М. Хуторян, Ф.А. Цесарський, Г.В. Шонія та інші науковці, які розглянули нормативно-правову основу як у Європейському Союзі загалом, так і в різних країнах зокрема.

Метою статті є аналіз досвіду країн Європейського Союзу (наприклад, Франції) у галузі нормативно-правового регулювання трудових відносин для подальшого використання його у вітчизняній практиці.

Виклад основного матеріалу. Розглядаючи досвід правового регулювання праці в країнах Європейського Союзу, необхідно звернути увагу на таку провідну державу, як Франція.

У тексті чинної Конституції Французької Республіки 1958 р. не проголошуються права й свободи громадянина. Лише в преамбулі до Конституції Французької Республіки вказується: «Французький народ урочисто 
проголошує свою прихильність правам людини і принципам національного суверенітету, як вони були визначені в Декларації прав і свобод людини й громадянина 1789 р., підтвердженій та доповненій у преамбулі до Конституції 1946 р.». Це дає підстави вважати, що Конституція Французької Республіки 1958 р. залишила в силі преамбулу Конституції Французької Республіки 1946 р., у якій було проголошено важливі соціально-економічні права, зокрема такі:

- право на працю («кожен повинен працювати та має право на отримання посади»);

- рівність усіх громадян у сфері праці («ніхто не може у своїй праці та у своїй посаді бути пригнобленим через своє походження»);

- рівність жінок і чоловіків («закон гарантує жінці в усіх сферах рівні права із чоловіком»);

- право на об’єднання та профспілку («кожна людина може захищати свої права й свої інтереси через профспілкову організацію та належить до профспілки за своїм вибором»);

- право на страйк («право страйків здійснюється в межах законів, які його регламентують»);

- право трудящих на колективні договори та на участь у керуванні підприємством («кожний трудящий через посередництво своїх делегатів бере участь у колективному визначенні умов праці, як і в керуванні підприємством») [2].

На сьогодні в Україні на законодавчому рівні закріплено право на працю. Так, у ст. 43 Конституції України прописано гарантії держави на створення умов для здійснення громадянами права на працю, рівні можливості під час вибору професії тощо [3]. Право на працю - це визначальне право для комплексу конституційних прав у соціально-трудовій сфері. У межах нашої держави основною визнається сучасна форма реалізації права на працю, сутність якої полягає не в гарантуванні надання роботи й забезпечення повної зайнятості, а у свободі вибору праці.

Положення преамбули Конституції Французької Республіки 1958 р. (далі - Конституція ФР) вважаються нормами, що мають пряму силу, які складають невід’ємну частину правової системи Франції. Згідно з Конституцією ФР закони можуть визначати лише фундаментальні принципи трудового права. Питання, що не входять до сфери законодавства, вирішуються в адміністративному порядку (ст. ст. 34, 37 Конституції ФР). Таким чином, Конституція ФР залишає парламенту право розробляти лише загальні принципи законодавства, реалізацію ж принципів передано уряду. Закони, які схвалені до набрання чинності Конституцією ФР, можуть бути замінені за допомогою урядових декретів (ст. 37 Конституції ФР). Конституція ФР не допускає прийняття парламентських пропозицій, які викликають збільшення бюджетних видатків (ст. 40 Конституції ФР). Уряд може отримати від парламенту повноваження видавати шляхом ордонансів норми, які зазвичай є предметом законодавства (ст. 38 Конституції ФР) [4, с. 11]. Ордонанси за своєю суттю є актами делегованого законодавства. На по- 
чатку дії Конституції ФР вони розглядались як винятковий захід, зумовлений надзвичайними обставинами. Однак згодом уряд і безпосередньо президент почали використовувати цю процедуру як звичайний метод у керуванні країною. Таким чином, можна констатувати, що наявна тенденція до зрівняння законів та актів урядових органів.

Деякі норми у галузі праці містяться в спеціалізованих кодексах (у Сільському кодексі Французької Республіки, у Кодексі регулювання праці моряків торгового флоту Французької Республіки, у Кодексі регулювання праці на заморських територіях Французької Республіки). Багато інших питань трудового права регламентуються Цивільним кодексом Французької Республіки. Зокрема, його норми широко застосовуються щодо трудового договору [5, с. 212].

Окрема роль у трудовому законодавстві Франції відводиться актам, виданим урядом щодо делегування парламенту: законам (у період Третьої та Четвертої республік) та ордонансам (у період П'ятої республіки) [1, с. 96].

Декрети міністрів, а також префектів визначають правила застосування законів до конкретних галузей чи регіонів [6, с. 174]. Велике значення мають декрети міністра праці, які розповсюджують дії колективних договорів. Зазвичай у декретах закріплюються правила техніки безпеки й виробничої санітарії [5, с. 108].

Колективні договори укладаються в галузевому масштабі або в межах підприємств. Існують також колективні договори, які діють у масштабах усієї промисловості (загальнонаціональні міжконфедеральні угоди), та такі, що регулюють питання вихідної допомоги, допомоги по безробіттю, професійного навчання, колективного звільнення, відпустки, допомоги за вагітністю й пологами $[7$, с. 41$]$. Таким чином, колективні договори розділяються на загальнонаціональні, галузеві, регіональні та колективні договори підприємств. Вони містять положення, що належать усім категоріям робітників. Спеціальні доповнення стосуються робітників, майстрів, інженерів та інших осіб [8]. У сучасних умовах підприємці Франції вважають за доцільне впроваджувати трудові контракти індивідуального характеру, що закріплюють умови праці та норми, прописані в національному законодавстві й декретах. Колективні договори та угоди можуть їх покращити на користь робітників за рахунок коштів підприємців, тому останні користуються індивідуальними контрактами. Однак індивідуальні контракти все-таки погіршують матеріальний і соціальний статус робітника та створюють труднощі для підписання колективного договору на підприємстві.

Правила внутрішнього трудового розпорядку включають норми щодо дисципліни, техніки безпеки й виробничої санітарії, найму та звільнення, а також повинні обов'язково прийматись на промислових підприємствах, які налічують щонайменше 20 робітників. Ці правила розробляються керівником підприємства. Останній зобов'язаний лише проінформувати про іх склад комітет підприємства та делегатів персоналу, вислухавши думку, яку може й не прийняти [9, с. 270]. Згадані правила поширюються на всіх працівників незалежно від часу прийняття та виду робіт, які вони вико- 
нують. Отже, правила внутрішнього трудового розпорядку є локальним нормативним документом, їх зміст має враховувати специфіку діяльності підприємства, а не лише визначатися загальними нормами законодавства у сфері праці.

До важливих джерел трудового права належать рішення суду вищої інстанції - Касаційного суду Французької Республіки, а також рішення Конституційної ради Французької Республіки, яка визначає питання, що належать до фундаментальних принципів трудового права та $є$ водночас прерогативою парламенту. Конституційна рада Французької Республіки перевіряє відповідність прийнятих парламентом актів Конституції ФР. Специфічним джерелом трудового права $є$ рішення органів адміністративної юстиції, насамперед іï вищого органу - Державної Ради Французької Республіки [10, с. 65]. Використання арбітражу у сфері трудового права у Франції є досить рідким явищем. За юридичною силою рішення арбітражних органів прирівнюються до колективних договорів.

Роль міжнародних конвенцій як джерела трудового права визначається ст. 55 Конституції ФР, яка визнає пріоритет міжнародних договорів перед внутрішніми законами, якщо ці договори належним чином ратифіковані й використовуються іншою стороною [11, с. 76].

Міжнародне нормативно-правове регулювання у сфері праці стосується міграційної політики держави.

17 травня 2006 р. французька Assemblйе Nationale схвалила Закон Французької Республіки про міграцію та інтеграцію [12], згідно з яким французька політика у галузі міграції орієнтується на стратегію «виборчої / селективної міграції» (immigration choisie) та охоплюється трьома пунктами: «виборчою політикою щодо мігрантів, які приймаються», обов'язковою інтеграцією для тих, хто тривалий час перебуває в країні та/або на тривалий час в”іжджає в країну, «взаємодією/співпрацею» [13].

Політика виборчої/селективної міграції базується на введенні карти компетенції мігранта (carte competences et talents). Власники цих карт, згідно зі ст. 15 Закону Французької Республіки про міграцію та інтеграцію, будуть здійснювати свою трудову діяльність в обраному ними напрямі. За змістом ця карта призначена для полегшеного в’ізду в країну спеціалістів високої кваліфікації, учених і професіоналів, які необхідні «робочому ринку» Французької Республіки [14, с. 117]. Такий засіб слугує для залучення необхідних висококваліфікованих кадрів, яких не вистачає у Франції, 3 інших країн світу (наприклад, вузькопрофільних спеціалістів в атомній енергетиці тощо).

Стан зовнішніх міграційних процесів в Україні свідчить про те, що Україна через своє географічне розташування стала однією з основних транзитних країн на шляху міграції до країн Європейського Союзу. Водночас унаслідок складної економічної ситуації Україна сама перетворилася на одну 3 найбільших країн-донорів мігрантів до Європейського Союзу [15, с. 125]. Тому на сьогодні в Україні $є$ актуальним розроблення правильної «виборчої політики», яку буде скеровано на зменшення потоку незаконних 
мігрантів шляхом введення картки мігранта, що допоможе залучати висококваліфіковані кадри на вільні робочі місця.

Другим важливим елементом міграційної політики Франції є обов'язковий договір про інтеграцію (contract d'accueil et d'intŭgration) згідно зі ст. L311-9 Закону Французької Республіки про міграцію та інтеграцію, що зобов'язує мігранта (як такого, який живе в країні, так і такого, який уперше в"їжджає на іiі територію) докласти всіх зусиль для інтеграції в суспільство, яке його приймає, стати членом якого-небудь суспільного утворення (церковного хору, футбольної команди тощо) та засвоїти мову до необхідного законом рівня. Такі елементи міграційної політики є доцільними та досить важливими для Франції, якщо порівнювати з Україною [16, с. 76].

Висновки. Отже, для України в аспекті нормативно-правового регулювання трудових відносин на основі досвіду Французької Республіки потрібно запозичити прийняття «виборчої політики» для мігрантів шляхом упровадження картки мігранта, яка допоможе залучати країні на вільні робочі місця лише потрібні висококваліфіковані кадри, а також боротись із нелегальним потоком мігрантів до країн Європейського Союзу.

Важливого значення для розвитку в Україні цивілізованих соціально-трудових відносин, які відповідали б ринковій економіці, усім потребам суспільства, набуває досвід регулювання трудових відносин країн - членів Європейського Союзу. Рівня високого соціально-економічного розвитку в цих державах було досягнуто за допомогою співпраці із соціальними партнерами. Тому досвід розвинених країн дає змогу стверджувати, що високі соціально-економічні результати досягаються на умовах соціального партнерства, коли кожен з учасників регулювання соціально-трудових відносин бере на себе відповідальність та відповідає за прийняття й упровадження взаємоприйнятих рішень і збереження соціального миру.

\section{Література}

1. Козик А.Л. Международное и национальное трудовое право (проблемы взаимодействия) / А.Л. Козик, К.Л. Томашевский, Е.А. Волк. - Минск : Амалфея, 2012. - 244 с.

2. Загальна характеристика Конституції Французької республіки 1958 р. [Електронний ресурс]. - Режим доступу : http://pidruchniki.ws/15890315/pravo/konstitutsiyne_pravo_frantsiyi.

3. Конституція України : Закон України від 28 червня 1996 р. № 254к/96-ВР [Електронний pecypc]. - Режим доступу : http://zakon5.rada.gov.ua/laws/show/254k/96-вр.

4. Шония Г.В. Общая характеристика трудового права Франции : автореф. дисс. ... канд. юрид. наук : спец. 12.00.05 «Трудовое право; право социального обеспечения» / Г.В. Шония ; МГЮА. - М., 2009. - 31 с.

5. Сироїд Т.Л. Міжнародне право : [навч. посібник] / Т.Л. Сироїд. - Х. : ХНУВС, 2009. - 335 с.

6. Капустин А.Я. Европейский Союз: интеграция и право : [монография] / А.Я. Капустин. М. : Из-во РУДН, 2000. - 436 с.

7. Гетьманцева Н.Д. Міжнародні договори у сфері праці / Н.Д. Гетьманцева / / Науковий вісник Чернівецького університету / відп. ред. П.С. Пацурківський. - Чернівці : Рута, 2002. Вип. 147 : Правознавство. - С. 41-44.

8. Система оплаты труда во Франции [Електронний ресурс]. - Режим доступу : http:// www.tinlib.ru/delovaja_literatura/evropeiskie_sistemy_oplaty_truda/p4.php.

9. Вітер В.І. Європейські трудові стандарти як орієнтир для України / В.I. Вітер / / Міжнародне економічне співробітництво України (правові проблеми) : матер. міжнар. наук.-практ. конф. (м. Київ, 18 листопада 2004 р.). - К. : Київський нац. економ. ун-т, 2004. - С. 267-275. 
10. Цесарський Ф.А. Співвідношення норм національного трудового права й міжнародно-правових актів у регулюванні інституту трудового договору / Ф.А. Цесарський / / Проблеми законності. - Х. : Нац. ун-т «Юрид. академія України ім. Я. Мудрого», 2012. - Вип. 119. - С. 102-109.

11. Гредякін Д.О. Особливості взаємодії права Європейського Союзу та міжнародного права в контексті Лісабонського договору / Д.О. Гредякін / / Зовнішня торгівля: економіка, фінанси, право. - 2010. - № 1. - С. 75-79.

12. Loi du 24 juillet 2006 relative a l'immigration et a l'intügration № 2006-911 [Електронний pecypc]. - Режим доступу : http://www.vie-publique.fr/actualite/panorama/texte-vote/loi-du24-juillet-2006-relative-immigration-integration.html.

13. Chou M.-H. The 2006 French Immigration and Integration Law: Europeanization or Nicolas Sarkozy's Presidential Keystone? / M.-H. Chou, N. Baygert / / Working Paper. - 2007. - № 45. - P. 5 .

14. Венедіктов С.В. Правове регулювання трудових відносин: вітчизняний та зарубіжний досвід : [навч. посібник] / С.В. Венедіктов. - К. : Алерта, 2012. - 368 с.

15. Завгородня В.М. Правове регулювання часу відпочинку в трудовому праві Європейського союзу та країн-членів / В.М. Завгородня / / Правовий вісник Української академії банківської справи. - 2011. - № 2(5). - С. 123-128.

16. Гредякін Д.О. Особливості взаємодії права Європейського Союзу та міжнародного права в контексті Лісабонського договору / Д.О. Гредякін / / Зовнішня торгівля: економіка, фінанси, право. - 2010. - № 1. - С. 75-79.

\section{Ано т а ц і я}

Чижмарь Ю. В. Сучасний стан нормативно-правового регулювання трудових відносин у Франції. - Стаття.

У статті на прикладі Франції розглянуто стан нормативно-правового регулювання трудових відносин у країнах Європейського Союзу. Виділено основні риси політики Франції в галузі трудового права. Зроблено висновки шляхом виділення тих елементів, які потребують запровадження в Україні.

Ключові слова: Європейський Союз, трудові відносини, виборча політика, нормативно-правове регулювання, конституція.

\section{Ан нот а ция}

Чижмарь Ю. В. Современное состояние нормативно-правового регулирования трудовых отношений во Франции. - Статья.

В статье на примере Франции рассмотрено состояние нормативно-правового регулирования трудовых отношений в странах Европейского Союза. Выделены основные черты политики Франции в сфере трудового права. Сделаны выводы путем выделения тех элементов, которые нуждаются в применении в Украине.

Ключевые слова: Европейский Союз, трудовые отношения, избирательная политика, нормативно-правовое регулирование, конституция.

\section{S u m m a r y}

Chizhmar Iu. V. Current state of regulation of labor relations in France. - Article.

In the article with the example of France condition of normative-legal regulation of labor relations in European Union was examined. The main peculiarities of France's politics in labor relations field were described. The conclusions were made by means of highlighting of the elements that need to be implemented in Ukraine.

Key words: European Union, labor relations, selective politics, normative-legal regulation, constitution. 